\title{
Analysis of Dormitory Inventory Information System Design Based on Microsoft Access in PT. Infineon Technologies Batam
}

\author{
$1^{\text {st }}$ Yosi Yolanda \\ Applied Business Administration \\ Batam State Polytechnic \\ Batam, Kepulauan Riau \\ yosiyolanda150597@gmail.com
}

\author{
$2^{\text {nd }}$ Sri Zuliarni \\ Applied Business Administration \\ Batam State Polytechnic \\ Batam, Kepulauan Riau \\ sri.zuliarni@polibatam.ac.id
}

\begin{abstract}
Dormitory inventory is one of the facilities provided by the company to employees who stay at PT. Infineon Technologies Batam dormitory. This research has designed an information system based on Microsoft Access that is used to record inventory that goes into the warehouse, exits the warehouse, and is in the warehouse. Observation, interview and documentation were used to get pictures of the existing dormitory inventory data. The information system designed has provide information related to dormitory inventory data more easier, faster and accurate.
\end{abstract}

Keywords- Dormitory Inventory, Information System Dormitory Inventory, Microsoft Access.

\section{INTRODUCTION}

\subsection{Background}

The industrial sector is a sector that has been developed by the government for many industry sectors to help the country's economic growth. Economic development in a country in the long term period will bring fundamental changes in the economic structure of the country, namely from the traditional economy focused on the agricultural sector to a modern economy dominated by the industrial sector (Tambunan, 2001).

Riau Islands is one of the largest industrial cities in Indonesia. This indicated by the increase in production large and medium manufacturing industries in the first quarter-2018 according to the Province, which experienced growth of $3.55 \%$ from the previous quarter and $14 \%$ from the previous year.

Besides, the development of the manufacturing industry sector in Batam is the leading sector that contributes the most to the Gross Regional Domestic Product (GRDP) compared to other sectors. This is based on the contribution of the manufacturing industry's output during the 2015-2017 periods.

The industrial area is an area dominated by industrial activities that have combination facilities consisting of industrial plants, research facilities, and laboratories for development, office buildings, banks, and social facilities and public facilities (Dirdjojuwono, 2004). One of the industrial estates in Batam is Batamindo. Batamindo industrial area is an industrial area located in the Yellow Front area with an area of around $320 \mathrm{Ha}$ and is the first largest industrial area in the city of Batam. There are 30 companies in the Batamindo area, one of which is PT Infineon Technologies Batam.

The importance of job satisfaction from users, furthermore the service that is employee loyalty is inseparable from factors in the work, such as wages, supervision, work peace, and working conditions. Unfortunately, until now the activity of recording the dormitory inventory of PT Infineon Technologies Batam is still manually so that it is considered less effective and efficient, resulting in frequent recording errors so that there is a need for an information system based on Microsoft Access that can manage dormitory inventory data management".

Based on the description of the background, the authors are interested in researching the title "Analysis Of Design Dormitory Inventory Information System Microsoft AccessBased in PT Infineon Technologies Batam”.

\subsection{Formulation of the problem}

Based on the background described above, the formulation of the problem of this study is:

1. What is the dormitory inventory procedure at PT Infineon Technologies Batam?

2. How to design the dormitory inventory information system at PT Infineon Technologies Batam?

3. What is the implementation of the dormitory inventory information system at PT Infineon Technologies Batam?

4. How to evaluate the implementation of the dormitory inventory information system at PT Infineon Technologies Batam?

\subsection{Research Purpose}

Based on the formulation of the problem above, as for the objectives to be achieved from the research conducted are:

1. To analyze the dormitory inventory procedure at PT Infineon Technologies Batam.

2. To design a dormitory inventory information system at PT Infineon Technologies Batam.

3. To implement the dormitory inventory information system at PT Infineon Technologies Batam. 
4. To evaluate the application of dormitory inventory information systems at PT Infineon Technologies Batam.

\subsection{Benefits of research}

The benefits of the research to be performed are:

1. For companies are as input in the development of information and administrative systems that can be applied handle existing dormitory inventory data in warehouses using information systems designed to be more effective and efficient.

2. For the researcher is a form of implementation of relevant knowledge and improvisation warehousing system by studying the design of a warehouse information system applications.

3. For other researchers are as additional insights in the design of information systems and warehousing applications as well as a reference for the parties concerned.

\section{FOUNDATION OF HYPOTHESIS THEORY AND DEVELOPMENT}

\subsection{Literature Review}

A. Data

According to Sutabri (2012), data is a reality that describes an event and is still a raw form that has not been able to tell much so it needs to be further processed through a model to produce information.

\section{B. Objects in Microsoft Access}

Objects in Microsoft Access according to Ashari (2005), consist of:

1. Table

The table is a set of data or specific information about a particular subject arranged in the form of rows and columns.

2. Query

Queries can be interpreted by defining data, namely manipulating and controlling the manipulation through language.

3. Form

The form is used to display the required fields and labels that will be used in entering in a table or query

4. Report

The report is the endpoint of the database creation process in Microsoft Access. The report will give an overview to the user about the final results of data processing using the Microsoft Access program.

5. Switchboard

A switchboard is an object that serves to facilitate the organization of menus that exist in an application program designed using Microsoft Access.

\section{Database}

According to Sutarman (2012), a database of interconnected and organized files or a collection of records that store data and relationships between them.

\section{Dormitory}

The dormitory in Indonesian is called a dormitory. The dormitory is a residential building for groups of people who are homogeneous (Big Dictionary of Indonesian Language, 1995).

\subsection{Framework}

The mindset is a view of mindset in the form of a diagram that outlines the flow of an outline study.

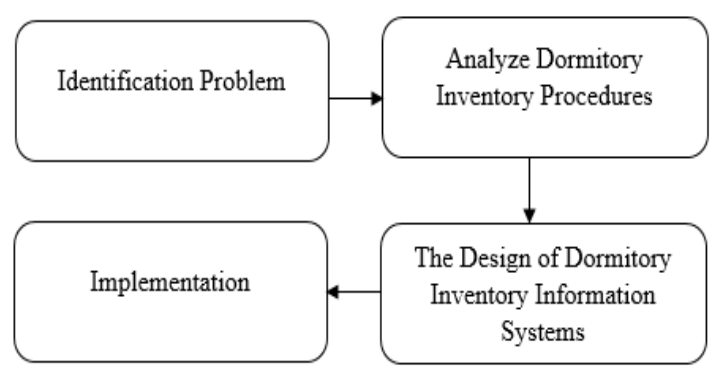

Fig. 1. Framework

\section{RESEARCH METHODS}

\subsection{Research Design or Design}

Design or research design is used as planning, drawing and making sketches or arrangements from several separate elements into a single unit that is intact and functioning properly and correctly. Aiming to describe and explain how the process of input (input) in the form of data obtained, then analyzed to be able to find the main solution of existing problems with methods or methods designed so as to produce a system that can reduce and even solve obstacles that previously existed in a system. The flow of data or information flowing in the study can be illustrated by the design of the research conducted.

\subsection{Objects and Scope Research}

The object of this research is the dormitory inventory information system at PT Infineon Technologies Batam. The dormitory inventory is stored in a warehouse inside the PT Infineon Technologies Batam area. The items stored in this warehouse are stocks of equipment and equipment provided by PT Infineon Technologies Batam for new employees residing outside of Batam City who will live in a dormitory.

The scope of this research includes admin management, management of dormitory inventory data, management of employee data, management of incoming goods transactions and management of goods transactions out of dormitory inventory and dormitory inventory reports at PT. Infineon Technologies Batam 


\subsection{Types and Data Sources}

The research conducted is exploratory research and the approaches used include: information systems, inventory, warehouses, and Microsoft Access software applications. There are 2 (two) sources of data in this study, namely:

\section{Primary Data}

Obtained by conducting interviews with parties related to the research as well as conducting direct observations of the objects to be studied, use the data in the form of data the warehouse office aimed at collecting data as the main source.

2. Secondary data

Obtained indirectly from the object of research

\subsection{Data Collection Technique}

The researcher conducted a study using a case study method with field research techniques, namely the technique of collecting data through a careful and systematic data collection process on objects that will be directly observed in the management of dormitory inventory at PT Infineon Technologies Batam. The field research method used is as follows:

1. Observation

2. Interview

3. Documentation

\subsection{Data Analysis Method}

This research is qualitative research. The data analysis method used in this study is a descriptive method that aims to find and arrange appropriately and sufficiently from all activities of objects, processes, and human. In this study, the design of the method used is summarizing several large amounts of raw data that can be interpreted as the information. The data in question is the result of an interview with the HR Administrator who is responsible for employee housing and who is responsible for purchasing inventory items dormitory. In this study, data collected from interviews and documentation studies will be analyzed qualitatively and described in descriptive form. Data processing is the following ways:

1. Reduction

2. Processing data

3. Drawing conclusions

4. Simulation and Implementation

\section{RESULTS AND DISCUSSION}

\subsection{Designing a Standard Operating Procedure (SOP)}

The running procedure analysis systematically describes the activities that occur in the process of recording the data of the dormitory inventory in the dormitory warehouse. So that the information system development process stages can run well and smoothly, for more details it will be described using modeling that is used to use the information system flowchart.
1. Flowchart of the Dormitory Inventory Procurement

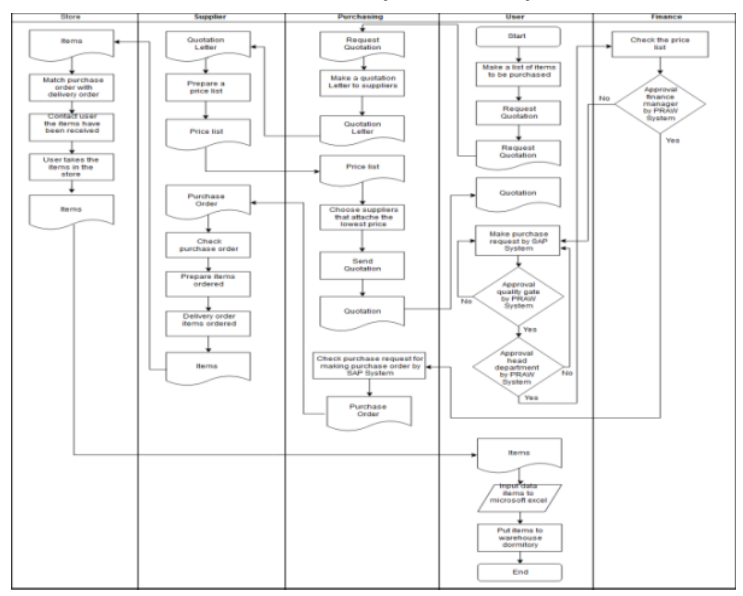

2. Dormitory Inventory Taking Flowchart

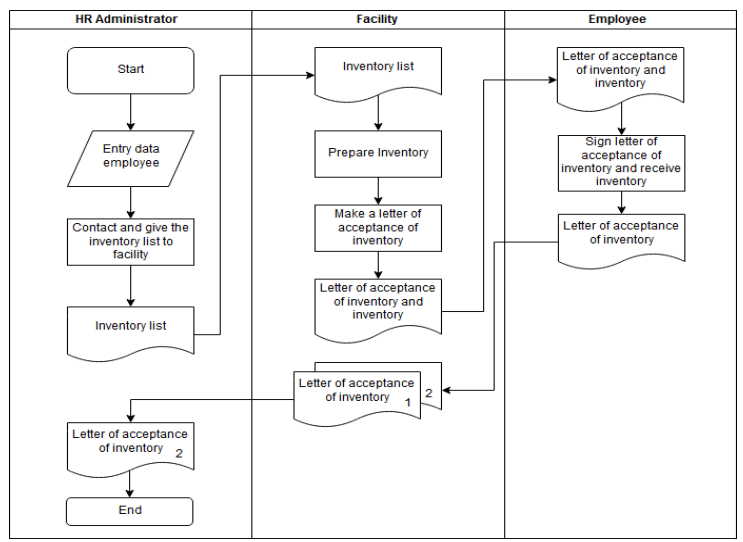

3. Database Planning Process and Dormitory Inventory Information System

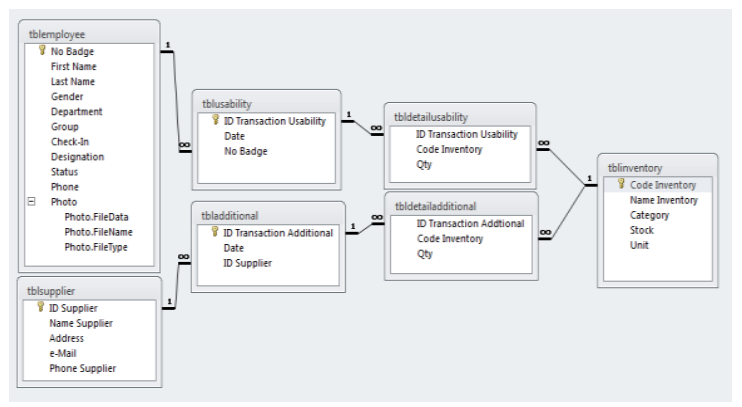

From the figure states that there is a relationship that occurs in a table with a table whose function aims to regulate database operations. The design of table relationships is displayed based on the tables that have been created and used as data sources for designing forms and reports in the dormitory inventory database.

\subsection{Interface of Dormitory Inventory Information System}

A. Display Splash screen Form is the initial display when opening a database inventory dormitory. Below the display form splash screen 


\section{(infineon \\ Human Resource Department \\ P. rosil Yolanda 1121501060}

B. Display Main Menu Switchboard is the main menu display when opening the dormitory inventory database. On the Main Menu Switchboard has 5 main menu buttons, namely: switchboard admin, switchboard data entry, usability inventory, additional inventory, and custom report. Following is the display of the Main Menu Switchboard:

Main Menu Switchboard
Inventory Dormitory PT. Infineon Technologies Batam
- Switchboard Admin
- $\quad$ Switchboard Entry Data
- $\quad$ Additional Inventory
- $\quad$ Custom Report

C. The switchboard menu admin displays the main menu when going open the admin form. On the Main Menu Switchboard has 2 buttons namely: add new admin and play the switchboard menu.

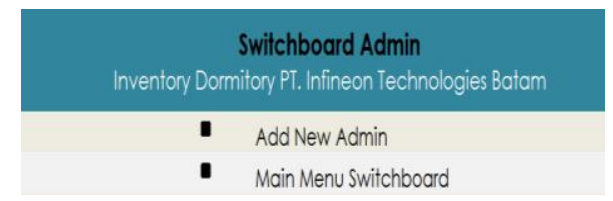

D. Switchboard Entry Data Display Menu is the main menu display when opening the supplier data form, employee data, and inventory data. Following is the Switchboard Entry Data Menu display:

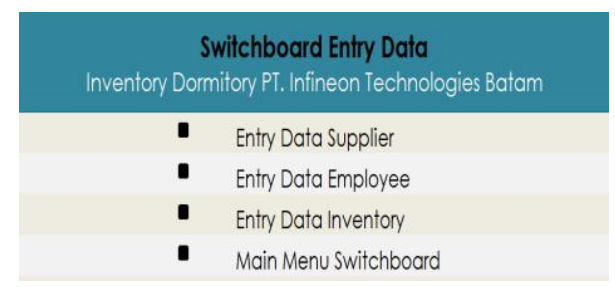

E. Switchboard Usability Inventory display is the main menu display when you open the usability inventory form. Next is the switchboard usability inventory display:

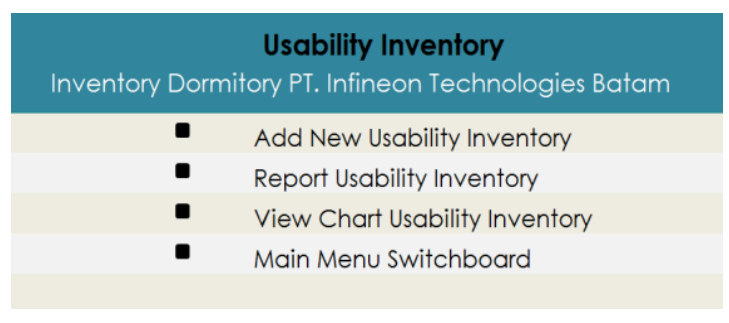

F. Display Switchboard Additional Inventory is the display of the main menu when it opens an inventory order form. Here's the switchboard additional inventory display:

Additional Switchboard
Inventory Dormitory PT. Infineon Technologies Batam
-
-
Additonal Inventory
View Chart Additional Inventory
Main Menu Switchboard

G. Display Switchboard Custom Report is the main menu display when it will open the custom report employee form and custom report inventory. Next is the switchboard custom report display:

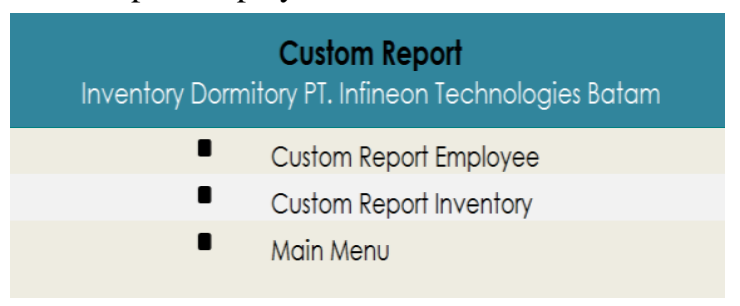

4. Dormitory Inventory Information System Evaluation

A. Ease of Use The ease of use of the application, according to the HR administrator responsible for employee housing is appropriate and makes it easy to access needs.

B. Content, the information system according to the HR administrator responsible for employee housing has been fulfilled for the needs of companies and have good material.

C. Satisfaction, from the satisfaction factor of this information system user, according to the HR administrator responsible for employee housing, the convenience can be felt by the user and they plan to use this information system continuously in his work.

\section{CONCLUSIONS AND SUGGESTIONS}

\subsection{Conclusion}

Based on the results of research on the analysis of design dormitory inventory information systems Microsoft Accessbased in PT Infineon Technologies Batam conclusions can be taken as follows:

1. The running procedure analysis systematically describes the activities that occur in the process of recording the data of the dormitory inventory in the dormitory warehouse. The dormitory inventory procedure is the SOP for the procurement of dormitory inventory and SOP for taking inventory dormitory.

2. Information system design Microsoft Access-based aims to input inventory dormitories in the warehouse. With this information system recording inventory data can be more automated and to update stock calculations can also be automatic. For data security, this system uses a login form 
system so that only people who have names and passwords can enter the system so that data security is guaranteed.

3. Implementation of the application of information systems that have built can simplify and accelerate the recording of dormitory inventory data in the warehouse. With this information system, a process of recording incoming goods transactions, goods transactions, and stock items can be carried out. Besides, searching for data in a warehouse can also be easier. This system can provide information regarding dormitory inventory data more easily, quickly, and accurately.

4. There are three evaluations in this information system, the first is the ease of use of the application (Ease of Use), from the ease of use of the application, according to the HR administrator in charge of the employee housing. second is content, this information system according to the HR administrator responsible for the employee housing has been fulfilled for the needs of the company and has good material and the third is satisfaction that is from the satisfaction of users of this information system according to HR administrators who are responsible for employee housing user and plans to use this information system continuously in his work.

\subsection{Suggestion}

Based on the research that has been done, suggestions that can be taken into consideration for research and also for future companies are as follows:

1. Dormitory inventory procedures, both procedures for procuring dormitory inventory and taking dormitory inventory that has implemented can run systematically outlining the activities that occur in the process of recording the dormitory inventory data in the dormitory warehouse. However, dormitory inventory procedures still need to be considered and developed to adjust to the growing company.

2. The design information system Microsoft access-based is upgraded with a Web-based information system so that in the future it can be easily accessed and can be used multiuser. Users can open and change the system at the same time. So, the Manager can monitor the state of the dormitory inventory directly and the HR Purchaser Inventory section can see inventory stock if it is thinned or used up can be purchased directly without having to wait for direction from Manager or HR Administrator at employee housing.

3. Implementation of the application of information systems can be developed with the addition of visualization plans for the location of goods laying, more quickly in the search for goods in the warehouse or can by using a barcode system so that data collection of dormitory inventory in warehouses can be easier and faster.

4. The overall evaluation of this system must continue to be developed along with the development of the company, therefore to have maintenance and system upgrades regularly so that it can be adjusted to the needs of the company.

\subsection{Limitations}

The limitations of the research that has done are as follows:

1. The research focused on designing information system on Microsoft access-based and only applied to PT Infineon Technologies Batam because this information system was developed based on the needs of interviews and observations directly.

2. The application of data in the company can only be taken some data due to licensing factors from the company.

\section{REFERENCES}

[1] T. Sutabri, Analisis Sistem Informasi, Yogyakarta: CV Andi Offset, 2012.

[2] Dirdjojuwono, R. W. ( 2004). Kawasan Industri Indonesia. Bogor: Pustaka Wirausaha

[3] Ashari, Pemograman Akuntansi untuk Usaha Dagang Menggunakan Microsoft Access, Jakarta: Elex Media Komputindo, 2005.

[4] Kamus Besar Bahasa Indonesia, Balai Pustaka, 1995.

[5] Sutarman, Buku Pengantar Teknologi Informasi, Jakarta: Bumi Aksara, 2012.

[6] T. Tambunan, Transformasi Ekonomi di Indonesia Teori dan Penemuan Empiris, Jakarta: Salemba Empat, 2001. 